\title{
Purchase Price Allocations: Do they Matter?
}

\author{
Pierre Astolfi \\ University Paris-Dauphine, pierre.astolfi@ dauphine.fr \\ Luc Paugam \\ University Paris-Dauphine, luc.paugam@ dauphine.fr \\ Olivier Ramond \\ University Paris-Dauphine, olivier.ramond@ dauphine.fr
}

This version: January 3, 2012

Acknowledgements. The authors gratefully acknowledge comments by Ryan Davies, participants at the CNAM workshop (Paris, October 2011). The authors are members of Dauphine Recherche en Management (DRM), CNRS Unit, UMR 7088. They acknowledge the financial support of the FBF Chair in Corporate Finance. 


\title{
Purchase Price Allocations: Do They Matter?
}

\begin{abstract}
:
Standards setters support that purchase price allocations (PPAs) enhance financial statement decision-usefulness whereas academics and practitioners challenge this statement. We test the consequences of the quality of PPAs, subsequent to business combinations, on change in market expectations. Using the concept of abnormal goodwill - as a proxy for PPAs' quality we test the association between PPAs' quality and analyst forecasts revisions, change in forecasts dispersion, and analysts' accuracy of 200 major U.S. business combinations. We do not find evidence that PPAs' quality have material impact on change in market expectations, suggesting that market participants fail to fully integrate information content of PPAs. Consistently, we provide evidence that PPAs' quality enables to generate a profitable investment strategy as cumulated abnormal returns can be systematically generated based on abnormal goodwill recognized in PPAs.
\end{abstract}

Keywords:

Purchase Price Allocation, Market Expectations, Abnormal Goodwill, Business Combination 


\section{Introduction}

The goal of financial reporting is to inform users about the true economic underlying of earnings. Recent evolutions put forward by U.S. and international standard setters resulted in a major change in terms of business combination accounting treatment: the purchase price has to be allocated to identifiable tangible and intangible assets, such as corporate trademark, customer relationship or backlog in order to improve the usefulness of financial statements. The identification and valuation process of acquired tangible and intangible assets, namely purchase price allocation (PPA), implies that goodwill has to be considered only as a residual.

However, there is still a case for competing positions between FASB/IASB and practical implementation of standards provisions relating to PPAs, with regard to earnings management. The FASB/IASB position is not completely supported by academics and practitioners, as they expressed concerns relating to the relevance of favoring separate recognition of intangible assets from goodwill.

These concerns are related to usefulness issues, i.e. the allocation of goodwill may be managed, as well as quality issues, i.e. the information disclosed may be uninformative for investors. In this context, this paper is the first to examine: (1) if analysts really care about information disclosed in the acquirer's purchase price allocation; (2) if the quality of the allocation is fully integrated into stock prices.

Our research question is the following: to what extent is the quality of purchase price allocation, required by standard setters, useful to financial statement users? In other words, do PPAs improve financial statements' usefulness for investors in making economic decisions with regard to capital allocation?

Our analysis is based on a unique hand collected dataset from acquirers' annual reports consisting in 241 major U.S. acquisitions, completed between 2002 and 2008. We focus first on assessing the quality of PPAs and second on testing the consequences of PPAs quality. Our results offer guidance for standard setters as we demonstrate that improving the quality of works undertaken to conduct PPAs, required by standards is not, by itself, sufficient to imply an increase of usefulness for users. As a result, we provide a major contribution to the current debate between academics and standard setters regarding the potential effects of accounting standards on financial markets. 
Our research question raises a difficulty because the quality of work undertaken to allocate purchase prices on acquired net assets is not directly observable. Consequently, to address this issue, we implement a two-step approach. First, we estimate a proxy for the quality of the allocation of the purchase price following a business combination. This proxy is based on the notion of abnormal goodwill, initially suggested by Shalev (2009). Abnormal goodwill is defined as the portion of the purchase price allocated to goodwill differing from the expected amount, considering some key underlying economic factors (e.g., sector, performance, growth expectations). Second, we test the effects of PPAs's quality on investors' change in expectations, defined as financial analysts (forecasts' revisions, change in dispersion, change in accuracy), and market as a whole (cumulated abnormal returns). We further provide tests regarding the robustness of our approach to capture PPA's' quality.

Our results suggest that the quality of PPAs has no strong effect on change in market expectations. Analysts, like the market, do not pay much attention to the quality of PPAs disclosed by acquirers. However, we point out evidence that, if a good PPA does not seem to impact market participants' decisions, a profitable investment strategy may be developed based on the portion of abnormal goodwill recognized in PPAs. Indeed, predictable cumulated abnormal returns (hence potential mispricing) can be identified ex ante, on the basis of abnormal goodwill.

The remainder of the paper is organized as follows. Section 2 summarizes the related literature and develops our research question. Section 3 exhibits our methodology. Section 4 presents our data. We show and comment our results in section 5. Concluding remarks are proposed in section 6 .

\section{Overview of Related Literature}

\subsection{Business Accounting Treatment: Towards Recognition of Intangible Assets Separately From Goodwill}

Business combination accounting treatment has been a very controversial case since the Accounting Principles Board issued APB 16 (AICPA 1970a) and APB 17 (AICPA 1970b), respectively dedicated to business combinations and intangible assets. In 2001, FASB clearly pronounced itself in favor of the recognition of intangible assets separately from goodwill (FASB 2001a). The IASB, issuing IFRS 3 in 2004, converged towards this position (IASB 2004). 
One reason for promoting this orientation is clearly expressed by the IASB in 2004. According to IFRS 3.BC 89, "The Board also agreed with the conclusion reached in IAS 22 and by the Canadian and U.S. standard-setters that the usefulness of financial statements would be enhanced if intangible assets acquired in a business combination were distinguished from goodwill."

More recently, and within the project of the convergence process with the FASB, the IASB stated that: "Both the IASB and the FASB decided that they needed to provide explicit criteria for determining whether an acquired intangible asset should be recognized separately from goodwill. The FASB provided such criteria in SFAS 141 and the IASB provided similar, although not identical, criteria in IAS 38.2. One reason for providing such criteria was the boards' conclusion that the decision-usefulness of financial statements would be enhanced if intangible assets acquired in a business combination were distinguished from goodwill."

Yet, academics as well as practitioners expressed some concerns regarding both usefulness and quality of financial statements disclosed by provisions of SFAS 141 and SFAS 141R. These concerns may contradict the objective of usefulness targeted by the FASB.

\subsection{Concerns Expressed}

\subsubsection{Usefulness of Purchase Price Allocations}

Jennings et al. (1996), Kanodia et al. (2004) or Skinner (2008), and some professional investors, ${ }^{2}$ support the idea that information disclosed relating to intangible assets by application of accounting standards are not useful to investors.

Already in 2001, in his report dedicated to strengthening financial markets, Garten $(2001,26)$ casts doubts on the real impact of accounting for intangible assets for equity valuation. $\mathrm{He}$ points out that "The value of a company is driven by its perceived ability to generate profits and cash flow. Intangible assets, by helping companies generate profits and cash flow, are a key indirect driver of value. This does not imply, however, that the value of a company's intangible assets translates directly into the value of the company as a whole."

Skinner is also not convinced of the usefulness of disclosures pertaining to intangible assets for equity valuation. Referring to Holthausen and Watts (2001), Maines et al. (2003, 180)

\footnotetext{
${ }^{1}$ IFRS 3 R BC 158

${ }^{2}$ See the IASB/FASB Joint Board Meeting of the CRUF, 22 ${ }^{\text {nd }}$ April, 2008. The CRUF (Corporate Reporting User's Forum) represents the interests of professional investors and analysts
} 
underlines that "The fact that voluntary disclosures of intangibles information are not widespread suggests that the net private benefits that accrue to firms from these disclosures are relatively small."

Similarly, Kanodia et al. (2004) underline that intangible assets, even when they are not identified, may be properly valued by financial market. The model suggested by Kanodia et al. takes into account concerns of the FASB regarding reliability of the value of intangible assets assuming that measurement of intangible is "necessarily noisy." Kanodia et al. (2004, 114) point out that "Empirical studies document a positive association between estimated intangible investments and stock prices and returns even when the accounting system does not explicitly measure and report intangibles." Nonetheless, they add that "These results do not necessarily imply that incorporating such estimates in formal accounting reports would actually provide new information to the market, nor do they imply that an outside observer could use these estimates to identify mispriced stocks and earn excess returns in the market."

Like Kanodia et al., Skinner (2008) argues that the main explanation of the difference between the book value and the market value is not the value of unrecognized intangible assets: market can value properly intangible assets even when they are not recognized in the balance sheet.

So, the position supported by Kanodia et al. (2004) contrasts with the idea according to which "it may appear that even a crude estimate for intangibles would be better than providing no information on intangibles." (p. 91). Actually, in some circumstances, a wrong estimate of intangible assets may result in a noise that market will try to undo. This noise may be not only useless, but could preclude correct valuation by investors.

According to Kanodia et al., "intangibles should be measured only when their relative importance in constituting the firm's capital stock is high and when they can be measured with sufficiently high precision." We can underline that this result is consistent with the position of IFRS 3 (IASB 2004) before its revision in 2008: fair value of intangible assets was required to be measured reliably to be accounted for.

This position has been reversed with the issue of IFRS 3 R (IASB 2008), according to which there is a presumption that all intangible assets (and not only intangible assets with a finite useful life) are measured reliably. 
Basu and Waymire (2008) also argue that "economic intangibles are cumulative, synergistic, and frequently inseparable from other tangible assets and/or economic intangibles not owned by any single entity," and add that "it is usually futile to estimate a separate accounting value for individual intangibles." They cast doubt on the ability to provide meaningful estimate of the individual value of intangibles.

\subsubsection{Quality Concerns: Purchase Price Allocations and Relations with Earnings Management}

In addition to the usefulness concerns highlighted above, accounting for business combinations may favor earnings management behaviors:

- before the issue of SFAS 141 in 2001 (FASB 2001a): earnings management consists in optimizing the choice of the accounting method (purchase method vs. pooling of interest method);

- after the issue of SFAS 141 in 2001: earnings management consists in optimizing measurement of intangible assets in order to minimize the impact of recognition and amortization on subsequent profit and loss statements.

\subsubsection{Purchase Price Allocations and Earnings Management before 2001}

On the one hand, some studies (Browning (1997); McGoldrick (1997); and Hopkins et al. (2000)) tend to show that stock prices for firms using purchase accounting method are penalized as compared with those of companies qualifying combinations for the pooling treatment. This impact would be caused by the effect, in the context of purchase method application, of goodwill amortization on earnings, despite this amortization has absolutely no impact on cash flows generated by the acquirer. As noted by Vincent (1997, 1), "conventional wisdom holds that share prices of purchase firms are penalized due to the reduced earnings resulting from goodwill amortization."

Some authors (e.g., Lys and Vincent (1995)) even reported that firms which succeeded in qualifying operation for pooling treatment were willing to pay a higher premium to target's shareholders than firms using purchase accounting method. 
Ayers et al. (2000) estimate that $15 \%$ of the premium paid in a context of a business combination is attributable to the possibility for the acquirer to secure a pooling accounting treatment.

Hopkins et al. (2000) contributed to this case investigating the extent to which analysts' valuation judgments are predictably affected by different methods of accounting for business combination. They demonstrate that target prices are negatively impacted by the choice of the purchase method. Conversely, target prices are higher if the method chosen is the pooling method or the in process R\&D method. According to Hopkins et al. (2000), this result can be explained by the potential impact of the purchase method on the net income disclosed by the acquirer.

Still, some studies (e.g., Jennings et al. (1996); Vincent (1997), Jenkins (1999)) document that market is unlikely to be mistaken by a non-cash impact accounting treatment. Price to be paid is supposed to be the same however favourable the accounting treatment is in terms of financial presentation, consistently with the efficient market hypothesis. According to these studies, investors adjust earnings so as to make earnings comparable, whatever accounting treatment related to business combinations is chosen by companies.

Jennings et al. (1996) and Vincent (1997) support this assertion. For example, supporting the conventional wisdom described above, research performed by Vincent $(1997,11)$ provides effectively evidence that "pooling firms enjoy an equity valuation advantage over purchase firms. There is no consistent evidence, however, relating this advantage to the differences in financial reporting." According to Vincent, "investors value pooling firms more highly, on average, than purchase firms in the years immediately following the business combination for reasons other than accounting."

In addition, Jenkins $(1999)^{3}$ points out that amortization of goodwill is a non-cash item and is accounted for over a very long period (most of the time, 40 years), reducing the impact of the amortization of goodwill on investors' judgment (see Henning and Shaw (2003)).

These studies tend to support the idea that "accounting debates are, in fact, arguments about nothing," as noted by Jenkins (1999), "in the sense that nothing in the real world changes just because you slap a different label on it." According to this position, financial accounting options related to business combinations do not provide any useful information to investors.

\footnotetext{
${ }^{3}$ Quoted by Hopkins et al. (2000).
} 
Similarly, according to Jennings et al. (1996), if goodwill accounted for (by application of purchase method) is effectively positively associated to the stock price of the acquirer, relation between stock price and amortization is very different from a firm to another: actually, analysts pay little attention to the selected accounting treatment.

\subsubsection{Purchase Price Allocations and Earnings Management after 2001}

Standard setters acknowledged, in 2008, date of the issue of IFRS 3 revised (IASB 2008), that previous standards provisions (IFRS 3) had not been properly applied: ${ }^{4}$ "Early in their respective projects on accounting for business combinations, the IASB and the FASB both observed that intangible assets make up an increasing proportion of the assets of many (if not most) entities. The boards also observed that intangible assets acquired in a business combination were often included in the amount recognized as goodwill." The Boards acknowledge that, until the issue of SFAS 141 and IFRS 3, standards did not meet the objective of reducing the proportion of goodwill accounted for in a context of a business combination, and so impacting the quality of financial statements.

From an academic point of view, some authors (see Shalev $(2009,243-245))$ recently pointed out that the quality of information disclosed relating to PPAs is actually varying from a firm to another. Zhang and Zhang (2007) support the idea that the end of pooling accounting method, which occurred after the adoption of FAS 141 in 2001, did not imply the end of the controversy neither the end of the interest for this issue. In fact, the debate now focuses on the extent to which new standards may exacerbate earnings management, so as to minimize the impact of amortization expenses on reported net income.

This incentive to earnings management is caused by the fact that the end of pooling accounting method (FAS 141, (FASB 2001a)) is associated with the end of goodwill amortization (FAS 142,(FASB 2001b)). This position results in opportunistic behaviours looking to optimize initial purchase price allocation so as to recognize more non-amortizable assets than amortizable assets.

This behaviour would be reinforced by the idea (see Watts (2003, 215); Ramanna (2008), Ramanna and Watts (2009)) that provisions of FAS 142, relating to impairment of goodwill, cause financial statements relying on unverifiable value estimates and on very subjective appreciations.

${ }^{4}$ IFRS 3 Revised BC 157 
Similarly, according to Ball (2006), the quality of the financial statements is largely impacted by the margin for manoeuvre which managers benefit to manipulate their financial statements. Now, IFRS 3/FAS 141R even offer issuers greater latitude in the opportunistic management of operating profits: the characteristics of those assets most concerned by IFRS 3/FAS 141R, i.e. intangible assets, often require fair value to be approached by a model in the absence of a liquid reference market.

This opposite effect is already identified by Ball $(2006,23)$ according to whom: "mark to model fair value accounting can add volatility to the financial statements in the form of both information $(\mathrm{a} « \operatorname{good} »)$ and noise arising from inherent estimation error and managerial manipulation (a "bad ») [...] Volatility is an advantage in financial reporting, whenever it reflects timely incorporation of new information in earnings, and hence onto balance sheets (in contrast with "smoothing," which reduces volatility). However, volatility becomes a disadvantage to investors and other users whenever it reflects estimation noise or, worse, managerial manipulation."

The specificity and the complexity of intangible assets explain in part the concerns expressed in the literature about the effective usefulness of the information supplied by the financial reports on these assets. More precisely, Zhang and Zhang $(2007,38)$ "predict and find that managers allocate more purchase price to goodwill relative to amortizable intangibles [post FAS 142] to reduce amortization expenses." They assert that management's reporting opportunism is a much more relevant driver to purchase price allocation than the underlying economics. As a result, managers may, on average, choose to allocate as much part of the price as possible to goodwill, considering its non-amortizable accounting treatment.

This impact of FAS 141 in terms of earnings management may result in providing investors with useless information. For instance, Watts $(2003,219)$ points out that "In moving into unverifiable valuation of the firm and non-separable intangible assets, the FASB is taking steps down a path that many before them have feared to tread, and with good reason. The likely result will be net asset values and earnings that are subject to more manipulation and, accordingly, are poorer measures of worth and performance."

These reserves expressed with regard to FAS 141 are closed to those relating to FAS 142. For instance, according to Ramanna and Watts $(2009,14)$ "Agency theory predicts managers (all else equal) will on average use unverifiability in accounting judgment, such as that in SFAS 142 impairment tests, to opportunistically manage financial reports." If Ramanna and Watts 
cannot exclude that the standard is, nevertheless, net beneficial, they highlight "the potential costs of unverifiable fair values in SFAS 142."

Consequently, issuing standards requiring separate recognition of intangible from residual goodwill, it seems that standard setters only favored the substitution of an old opportunistic behavior in terms of earnings management by a new one.

Some professional users support the same idea. For example, according to the Corporate Reporting Users' Forum, "The creation of new intangibles on acquisition (customer lists, brands, developed technology, etc.) is a return to goodwill amortisation by the backdoor but (...) it is even more arbitrary (choice of what to capitalise and amortization period is highly subjective)."

\subsection{Research Question}

To solve the current debate between academics and standards setters, we aim at answering the following research question: to what extent does the quality of purchase price allocations, required by standard setters, make them useful to financial statements users?

We assume that the quality of PPAs is a good proxy for measurement errors. Hence, we answer our research question using a model testing the consequences of measurement errors on decisions of market participants.

\section{Methodology}

We first explain how we estimate the quality of PPAs (paragraph 3.1), and then our approach to test the association between our proxy for PPAs' quality and change in forecasts' revisions, change in dispersion, and change in accuracy (paragraph 3.2). We finally expose our approach to assess the potential association between PPAs quality and security mispricing (paragraph $3.3)$.

\subsection{Determining the Quality of Purchase Price Allocations}

The first step of our approach aims at capturing the quality of PPAs by focusing on the amount of abnormal goodwill recognized following a business combination. Consistent with the methodology initially developed by Shalev (2009), high quality purchase price allocations should generate a level of acquired goodwill consistent with economic fundamentals (e.g., performance of the target, sector characteristics, expected growth). We estimate a model 
explaining the level of recognized goodwill following business combinations with underlying economic factors. As a result, similar to the discretionary accruals literature (e.g., Subramanyam (1996)), the abnormal portion of recognized goodwill is the residual of the model, i.e. the part that underlying economic factors do not explain. Abnormal goodwill serves as a proxy related inversely with the quality of the purchase price allocation since everything else equal, high quality PPAs should generate less abnormal goodwill. Model (1) explains the level of normal goodwill:

$$
\begin{gathered}
G W_{i}=c+b_{1} * \text { Materiality }_{i}+b_{2} * \text { Growth }_{i}+b_{3} * \text { Premium }_{i}+b_{4} * \text { Intan }_{i}+ \\
b_{5} * \text { BIG }_{i}+b_{7} * \text { sector }_{i}+b_{8} * \text { Year }_{i}+\varepsilon_{i}
\end{gathered}
$$

Where for firm $i$ :

- $G W_{i}$ is the amount of goodwill recognized in the PPA expressed as a percentage of the target firm's total asset (from Acquirers' $10-\mathrm{Q} / \mathrm{K}$ and Compustat);

- Materiality $i$ is the purchase price divided by the total assets of the acquiring company at the end of the quarter prior to completion of the acquisition (from Thomson One Banker and Compustat quarterly);

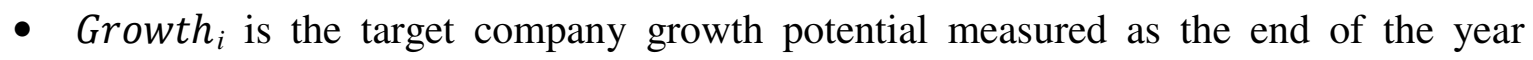
market-to-book ratio of the target (from Compustat annual and CRSP);

- Premium $_{i}$ is excess purchase price over the market value of equity of the target company measured at the end of the month prior to the announcement, expressed as a percentage of the market value of equity of the target company (from One Banker and CRSP monthly);

- $\operatorname{Intan}_{i}$ is the amount of total intangible assets in the balance sheet of the target company at the end of the year prior to acquisition (from Compustat annual);

- $B I G 4_{i}=1$ if the auditor of the acquiring company belongs to one of the 4 largest external auditors and 0 otherwise (from firm $10-\mathrm{Q} / \mathrm{K}$ );

- Sector $_{i}$ is a dummy variable controlling sector specific characteristics;

- $\operatorname{Year}_{i}$ is a dummy variable controlling the impact of the year during which the purchase price allocation was disclosed.

$\varepsilon_{i}$ is the error term in model (1) for firm $i$. After estimation of (1) the absolute value of residuals is labeled abnormal goodwill $(A b G W)$ in the other models presented hereafter and serves as a proxy for the quality of PPAs. 
We expect the following relation with the explaining variables:

- a negative relation between $G W$ and Materiality could be expected, since the relative size and hence visibility of the acquisition could reduce the managers' willingness to recognize a high level of goodwill. However, the relative size of the acquisition could capture a potential overpayment, and could inflate the amount allocated to goodwill. The expected association is therefore unknown;

- a positive relation is expected with Growth, since the growth potential of the target company would justify future profits and hence a high level allocated to goodwill; ${ }^{5}$

- a positive relation is expected between $G W$ and Premium, as high premium paid to acquire a target company may indicate an overpayment and increase the amount allocated to goodwill;

- a positive relationship is expected with the amount of intangible assets in the balance sheet of the target company prior to acquisition (Intan) as it might be a proxy for the quality of the target company. Everything else equals, firms able to generate and capitalize intangibles may have higher future profitability, justifying higher amounts allocated to goodwill;

- a negative relationship is expected between $B I G 4$ and $G W$ as better audit quality could lead to more identified intangibles and therefore a smaller recognized goodwill;

- finally, the dummies Sector and Years serve as controls for respectively the industry and the year. We do not expect any particular relations with $G W$.

\subsection{Testing the Association between Purchase Price Allocations' Quality and Change of Analysts' Expectations}

We answer our research question by testing the consequences of the quality of purchase price allocations (i.e. the effect of abnormal goodwill) on dependent variables measuring change of market expectations for the value of stock prices (change in analysts' expectations) and direct consequences on stock prices (changes in security prices). The second step aims at determining the extent to which PPAs are effective and mandatory disclosures required by SFAS 141 are effectively informative and useful for market participants. Using abnormal goodwill, defined as the absolute value of residuals of model (1), as an independent variable,

\footnotetext{
${ }^{5}$ Core goodwill equals the present value of abnormal earnings as expressed in the Ohlson (1995) model.
} 
we conduct three sets of tests for analysts' expectations and one set of test for market expectations as a whole.

\subsubsection{Association between PPAs' Quality and Revisions of Analysts' Expectations}

We examine the impact of the abnormal part of recognized goodwill (proxy for PPA quality) on revisions of analyst expectations (i.e. revision of target prices, earnings forecasts and recommendations) surrounding the disclosure of purchase price allocation.

$$
\text { Revision }_{i}=c+b_{1} * A b G W_{i}+e_{i}
$$

Where:

Revision $_{i}$ is defined as one the following four variables for acquirer $i$ :

- Revision $_{T P}$ is the change in the consensus (mean) target price following disclosure of the PPA in percentage of the mean target price before disclosure (from I/B/E/S);

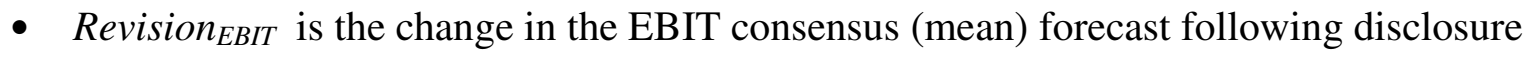
of the PPA in percentage of the mean EBIT forecast before disclosure (from I/B/E/S);

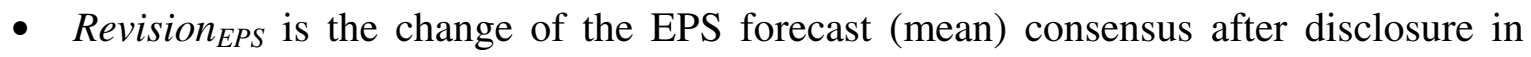
percentage of the mean EPS forecast before disclosure (from I/B/E/S);

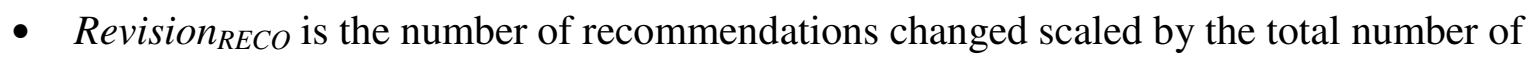
recommendations made by analysts following disclosure of the PPA (from I/B/E/S);

- $A b G W$ is the absolute value of residuals from model (1).

\subsubsection{Assocation between PPAs' Quality and Change in Forecasts' Dispersion}

We test the association between the quality of the PPAs and change of analysts' forecasts dispersion with model (3):

$$
\Delta \text { Dispersion }_{i}=c+b_{1} * A b G W_{i}+e_{i}
$$

Where $\Delta$ Dispersion $_{i}$ is defined for firm $i$ as the one of the following three variables:

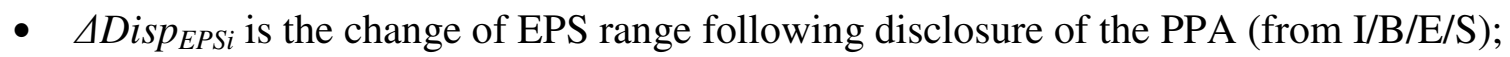

- $\triangle$ Disp $_{\text {EBITi }}$ is the change of EBIT range following disclosure of the PPA (from $\mathrm{I} / \mathrm{B} / \mathrm{E} / \mathrm{S})$; 
- $\triangle D_{i s p_{T P i}}$ is the change of target price range following disclosure of the PPA (from $\mathrm{I} / \mathrm{B} / \mathrm{E} / \mathrm{S})$.

With range is the absolute value of the difference between the most optimistic forecast (or target price) and the most pessimistic forecast, scaled by the mean forecast as detailed in equations below:

$$
\begin{aligned}
\text { Range }_{E P S} & =\operatorname{abs}\left(\frac{e p s^{\text {high }}-e p s^{\text {low }}}{e p S_{\text {mean }}}\right) \\
\text { Range }_{E B I T} & =a b s\left(\frac{e b i t^{\text {high }}-e b i t^{l o w}}{e b i t_{\text {mean }}}\right) \\
\text { Range }_{T P} & =a b s\left(\frac{T P^{\text {high }}-T P^{\text {low }}}{T P_{\text {mean }}}\right)
\end{aligned}
$$

\subsubsection{Assocation between PPAs' Quality and Change in Forecasts' Accuracy}

We also test if analysts' forecast accuracy improves with the quality of PPAs disclosed. Model (4) is estimated on our sample:

$$
\Delta \text { Error }_{i}=c+b_{1} * A b G W_{i}+e_{i}
$$

Where $\Delta$ Error $_{i}$ is defined for firm $i$ as one of the following two variables:

- $\triangle$ Error $_{\text {EBITi }}$ is the change after the disclosure of the PPA of the difference between EBIT forecasts and actual EBIT scaled by actual EBIT (from I/B/E/S);

- $\triangle$ Error $_{E P S i}$ is the change after the disclosure of the PPA of differences between EPS forecasts and actual EPS scaled by actual EPS (from I/B/E/S).

We also test the impact of PPA's quality on target price accuracy as:

$$
\% T P_{i}=c+b_{1} * A b G W_{i}+e_{i}
$$

Where for firm $i$ :

- $\% T P_{i}$ is the percentage of the target prices hit by the actual security prices over the next 12 month (Asquith et al. (2005)). 


\subsection{Association between PPAs' Quality and Cumulated Abnormal Returns}

To further investigate the valuation consequences of PPAs' quality, we measured cumulated abnormal returns by running an event study surrounding PPAs disclosures for 5 portfolios containing an equal number of companies, ranked on the basis of the level of abnormal goodwill recognized in the PPA. Portfolio 1 is composed of companies with the lowest proportion of abnormal goodwill (top 20\% PPAs' quality) whereas portfolio 5 is compose of companies with the highest portion of abnormal goodwill (lowest 20\% PPAs' quality). We then compare differences of CARs for the 5 portfolios.

\section{Data and Sample}

We obtained our sample from the deals analysis database of Thomson One Banker covering the period 2002-2008 with the following criteria:

- the deal has a value of at least $\$ 100$ million; $^{6}$

- both the target and the acquirer are listed US firms;

- the deal has been completed;

- the target macro-industry is high technology, healthcare, energy and power, or industrial.

Acquisitions during the period 2002-2008 were distributed between the different macroindustries as follows: finance (223), high technology (180), healthcare (133), energy and power (61), industrials (56), materials (48), consumer products and services (43), telecommunications (42), real estate (37), media and entertainment (36), consumer staples (30), retail (29), and government and agencies (1). We chose to study the 4 macro industries with the highest number of deals, excluding the finance sector which has specific disclosure requirements. Therefore we hand collected data for high technology, healthcare, energy and power, and industrial sectors.

455 business combinations between 2002 and 2008 met these criteria. Acquirers' 10-Q or 10$\mathrm{K}$ reports (depending on the date of acquisition), available from the SEC EDGAR database, were examined to obtain the purchase price allocations of these business combinations. The purchase price is allocated between current, tangible, and identifiable intangible assets, with the level of detail varying from one firm to another. Due to insufficient and missing

\footnotetext{
${ }^{6} \mathrm{~A}$ purchase price in excess of $\$ 100$ million increases the likelihood of finding relevant data in the acquirer's 10K/Q. Significant acquisitions also increase the likelihood of finding material impact of disclosures related to the acquisitions for market participants.
} 
disclosures in 10-Q and 10-K reports, the final sample comprises approximately 241 acquisitions with exploitable PPA data.

We then collect data to construct our variables from CRSP, Compustat, and I/B/E/S as described in section 4 . Table 1 provides some descriptive statistics of our sample.

\section{[Insert Table 1 About Here]}

From Table 1 Panel A, the mean (median) purchase price represents 3.17 (2.24) times total assets of the target companies (Price variable). We can also see that a significant part of the purchase price is allocated to goodwill, as the mean (median) recognized goodwill represents $57 \%(59 \%)$ of the purchase price. Our sample is composed of major acquisitions as the mean (median) purchase price represents 33\% (23\%) of the acquirers' total assets according to the variable Materiality. The sample is composed for $51 \%$ of acquisitions in the high tech sector, followed by $34 \%$ in the healthcare sector, $10 \%$ in industrial sector, and $5 \%$ of the energy and power sector.

Since variables for some firms are missing our tests are conducted on the largest sample available.

\section{Empirical Results}

\subsection{Determining PPAs' quality}

In order to determine PPAs' quality, we estimate model (1) on our sample. Results of the first step are displayed in Table 2 below.

\section{[Insert Table 2 About Here]}

From Table 2, materiality of the acquisition increases the amount of the purchase price allocated to goodwill, the growth options of the target, as proxied by the market-to-book ratio, are also positively associated with the amount of recognized goodwill. The amount of separately identified intangibles is positively associated with goodwill. Finally, acquirers in the high tech sector seem to recognize more goodwill as compared to the three other sectors. The adjusted $\mathrm{R}^{2}$ of our model appears satisfying, explaining more than $43 \%$ of the variance of recognized goodwill. This regression aims to capture the amount of normal goodwill, that is to say goodwill that should be recognized considering the underlying economic factors for the acquisition. 
Abnormal goodwill, defined as the absolute value of residuals from model (1), serves as a proxy for PPAs quality.

\subsection{Impact of PPAs' Quality on Analysts' Expectations}

In order to test whether PPAs' quality is associated with dependent variables capturing change in expectations about firms' values, we use the proportion of abnormal goodwill as an independent variable. We estimate model (2) to (5) to test the impact of the quality of PPAs on analysts' forecasts revisions (model (2)), change in dispersion (model (3)), change in accuracy (model (4)), and accuracy (model (5)).

Table 3 (Panel A to D) presents the results of our second step models.

\section{[Insert Table 3 About Here]}

From Table 3, a statistically significant negative association is obtained between abnormal goodwill and EPS and EBIT revisions (Panel A), and change in target price accuracy (Panel D). This would suggest that lower quality (higher abnormal goodwill) leads to lower EPS and EBIT revisions and would reduce target price accuracy. No association is observed between change in EPS and EBIT forecast dispersion or errors and PPAs' quality (Panel B and Panel C), suggesting that PPAs' quality is not related to forecast errors or analysts' accuracy.

Overall, from the 11 tests we conduct to test the impact of PPAs' quality only 4 are statistically significant (at the 10\% level). It appears that the quality of PPAs is not completely and systematically associated with change in analysts' expectations, whether we define expectations as forecast's revisions, change in dispersions, change in accuracy, or accuracy of analysts. In 7 of our 11 models, PPAs' quality appears to be unrelated to change in analysts' expectations. Analysts do not seem to fully consider the quality of PPAs to update their expectations. 


\subsection{Measuring PPAs' Quality: Robustness' Checks}

The absence of association between forecasts' revisions and PPAs' quality supported by results presented in Table 3 could be explained by the lack of power of our tests, simply because we would not have a valid proxy for PPAs' quality. To assess whether or not our variable $A b G W$ is a valid proxy, we conduct two tests: (1) we test if initial PPAs's low quality is associated with subsequent goodwill impairment testing management; (2) we also test if PPAs' quality is correlated with potential earnings management as measured by total accruals.

\subsubsection{PPAs' Quality and Subsequent Goodwill Impairment Testing Management}

We hypothesize that low quality PPAs are associated with subsequent goodwill impairment testing management. The underlying rationale is that firms manipulating goodwill initial recognition (during the PPA) are also likely to manipulate goodwill impairment tests when performance deteriorates during the years following the acquisition.

To test this hypothesis we estimated the two following models:

$$
\begin{gathered}
\operatorname{Imp}_{\% \text { EBITDA(i) }}=c+\operatorname{Perf}_{i}+\operatorname{LowPerf}_{i} * A b G W_{i}+e_{i} \\
\operatorname{Imp}_{\% T A(i)}=c+\operatorname{Perf}_{i}+\operatorname{LowPerf}_{i} * A b G W_{i}+e_{i}
\end{gathered}
$$

Where:

- $\quad$ Imp $_{\% \text { EITDA }(i)}$ is the total goodwill impairment charge for firm $i$ during the three years following completion of the acquisition expressed as a percentage of EBITDA (from Compustat annual);

- $\quad \operatorname{Imp}_{\% T A(i)}$ is the total goodwill impairment charge for firm $i$ during the three years following completion of the acquisition expressed as a percentage of three-year mean total assets (from Compustat annual);

- $\quad \operatorname{Perf}_{i}$ is the three-year mean performance of the acquirer measured as EBITDA/Total Assets (from Compustat Annual);

- $\operatorname{LowPerf}_{i}=1$ if firm $i$ is part of the $20 \%$ lowest performers of the sample measured as EBITDA/Total Assets during the three years following completion of the acquisition and $=0$ otherwise (from Compustat Annual);

- $A b G W_{i}$ is obtained from model (1) and proxies for PPAs' quality. 
Table 1, Panel D, presents some descriptive statistics of these variables and shows that goodwill impairments are large as a proportion of EBITDA or total assets.

We expect $\operatorname{LowPerf}_{i} * A b G W$ to be negatively associated with goodwill impairment, i.e. firms with low quality PPAs are manipulating future goodwill impairment tests when performance deteriorates and hence exhibit smaller impairment charges. We also expect that $\operatorname{Perf}_{i}$ is negatively associated with goodwill impairment, i.e. higher performance reduces goodwill impairment charges.

\section{[Insert Table 4 About Here]}

As expressed in Table 4, Panel A, the estimated coefficients are consistent with our hypotheses since firms with low performance and low quality PPAs (high level of abnormal goodwill) are associated with lower future impairment charges, whether expressed as a percentage of acquirers' EBITDA or total assets.

\subsubsection{PPAs' Quality and Total Accruals}

We also test if the amount of abnormal goodwill is positively correlated with total accruals. The underlying assumption is that firms managing earnings through accruals in their day to day financial reporting are also likely to manage earnings through purchase price allocations when a business combination occurs. This assumption is expressed in model (7) below:

$$
\operatorname{AbGW}_{i}=c+\text { Accruals }_{i}+e_{i}
$$

Where for firm $i$ :

- The variable Accruals $_{i}$ is the ratio of the absolute value of total accruals to the absolute value of cash flow from operations. Total accruals are calculated as follows: ( $\Delta$ total current assets $-\Delta$ Cash $)-(\Delta$ total current liabilities $-\Delta$ short term debt $)-$ depreciation expense. Cash flow from operation is equal to operating income minus total accruals (Burgstahler et al. 2006).

Table 4, Panel B, presents the results of model (7).

As total accruals are positively associated with abnormal goodwill, it confirms the validity of our proxy for PPAs' quality. It also constitutes evidence that firms managing earnings through the use of accruals are also more likely to manage PPAs. 


\subsection{Impact of PPAs' Quality on Security Prices}

To further investigate the impact of the quality of PPAs on market expectations, we run an event study centered on the disclosure of the PPA in the acquirer $10-\mathrm{Q} / \mathrm{K}$. If investors do not use information contained in PPAs, although they are informative, then it should be possible to use PPAs' quality to form a profitable trading strategy. Indeed, PPAs quality could proxy for the quality of the acquisition.

We divide the initial total sample is into five portfolios based on a ranking of the level of abnormal goodwill recognized in the PPAs: portfolio one includes companies that provide the top $20 \%$ of PPAs' quality, portfolio two is composed of firms providing the following $20 \%$ of best PPAs, etc. Portfolio five is contains firms providing the $20 \%$ worst PPAs, i.e. $20 \%$ of the initial sample with the highest level of abnormal goodwill.

We compute the benchmark returns using the Fama and French (1992) three factors model calibrated on the S\&P500 on 200 days ending 32 days prior to the event window. The cumulated abnormal returns are then computed during 50 trading days starting two days after the disclosure of the purchase price allocation in acquirers' $10-\mathrm{Q} / \mathrm{K}$ reports.

\section{[Insert Table 5 About Here]}

From Table 5, Panel A, we can see that firms exhibiting the lowest portion of abnormal goodwill (portfolio one) present positive cumulated abnormal returns $(+2.1 \%$ during 50 days, representing $10.60 \%$ annualized $^{7}$ ), whereas the two portfolios including acquirers with the highest portion of abnormal goodwill (portfolio four and five) exhibit negative cumulated abnormal returns (respectively $-2.83 \%$ and $-4.36 \%$ on 50 days, i.e. resp. $-14.15 \%$ and $-21.80 \%$ annualized). Additionally, the ranking of CARs for the five portfolios reflects exactly the ranking of PPAs' quality. Figure 1 shows the CAR' time series after disclosure of PPAs in acquirers' $10-\mathrm{Q} / \mathrm{K}$.

\section{[Insert Figure 1 About Here]}

These results are consistent with the hypothesis that market participants do not impound the information content of PPAs and therefore fail to correctly assess the value of securities following the disclosure of PPAs. A profitable trading strategy, consisting in shorting

\footnotetext{
${ }^{7} 10.60 \%=2.12 \% * 5$, assuming approximately 250 trading days a year.
} 
acquirers recognizing the highest level of abnormal goodwill and going long on acquirers recognizing the lowest level of abnormal goodwill appears to be possible.

We also computed buy and hold returns over 50 days following the disclosure of PPAs for the same five portfolio. As Table 5, Panel B exhibits, acquirers disclosing low quality PPAs lead to lower stock returns than acquirers disclosing high quality PPAs.

\section{Conclusion, Limitations, Discussion for Further Research}

Purchase price allocations (PPAs) following business combinations, mandated by accounting standards (FAS 141 in the U.S., and IFRS 3 in an international setting) require a large recognition of intangible assets separately from residual goodwill. Yet, this position is challenged by some academics (e.g., Garten (2001); Kanodia et al. (2004); Skinner (2008); Basu and Waymire (2008)) and by some practitioners (e.g.,CRUF (2008)). Indeed, concerns are expressed relating to usefulness issues of this requirement, and to quality issues. Earnings management behaviors are likely to be exacerbated in the context of a separate recognition of intangible assets.

This paper is the first to investigate the extent to which quality of PPAs, required by standard setters, improves financial statements' usefulness for investors (proxied by analysts or share returns) in making economic decisions with regard to capital allocation.

In order to address this question, and because the quality of work undertaken to conduct PPAs is not directly observable, we implemented a two steps approach on a unique hand collected data set, consisting of: first, computing a proxy of the quality of works undertaken by a firm in the context of PPAs, and second, testing the effects of PPAs' quality on usefulness of financial statements for users (analysts and other market participants).

We provide evidence that analysts, like the market as a whole, do not fully integrate information disclosed in PPAs. However, we find that PPAs' quality has an informative content, as high quality PPAs are predictably related to stock over performance, whereas lower quality's PPAs are related to future stock underperformance.

We contribute to the literature in several ways. Our study is the first to test the effects of PPAs' quality for market participants. Hence, our study contributes to standard setters' works, providing insights regarding the usefulness of standards issued and implemented, and regarding the extent to which a quite commonly understandable objective - improving 
information thanks to a more comprehensive recognition of intangible assets from goodwill ${ }^{8}-$ is likely to be met. As a result, this paper enters within the scope of the present context much more in favor of studies focusing on potential impacts of accounting standards.

However our study may suffer from a number of limitations. It may be limited by the sample we used. Indeed, we focused on U.S. firms, from 2002 to 2008. The results may not be generalized to other areas, following international standards for instance. Besides, our proxy for PPA's quality, although robust to some tests, may result in additional limitations: omitted variables may be associated to normal goodwill and distort our conclusions relating to abnormal goodwill, defined as the residual of our first step approach.

We suggest to further investigate the extent to which analysts and market as a whole pay attention to the informational content of PPAs. Studies could be conducted under an IFRS environment, and focus on the evolution over time of the quality of PPAs.

\footnotetext{
${ }^{8}$ See IFRS 3.89 and IFRS 3 R BC 158
} 


\section{References}

AICPA. 1970a. Accounting principles board (APB) no. 16: Business combinations. American Institute of Certified Public Accountants.

AICPA. 1970b. Accounting principles board (APB) no. 17: Intangible assets. American Institute of Certified Public Accountants.

Asquith, P., M. B. Mikhail, and A. S. Au. 2005. Information content of equity analyst reports. Journal of Financial Economics 75 (2): 245-282.

Ayers, B. C., C. E. Lefanowicz, and J. R. Robinson. 2000. The financial statement effects of eliminating the pooling-of-interests method of acquisition accounting. Accounting Horizons 14 (1): 1-19.

Ball, R. 2006. International financial reporting standards (IFRS): Pros and cons for investors. Accounting \& Business Research 36: 5-27.

Basu, S., and G. Waymire. 2008. Has the importance of intangibles really grown? And if so, why? Accounting \& Business Research 38 (3): 171-190.

Browning, B. 1997. Maximizing r\&d write-offs to reduce goodwill. Mergers and Acquisitions 32 (2): 29-32.

Burgstahler, D., L. Hail, and C. Leuz. 2006. The importance of reporting incentives: Earnings management in european private and public firms. The Accounting Review 81 (5): 145.

CRUF (2008) In April 22, 2008 FASB/IASB Joint Board Meeting.

Fama, E. F., and K. R. French. 1992. The cross-section of expected stock returns. Journal of Finance 47 (2): 427-465.

FASB. 2001a. Statement of financial accounting standards (sfas) no. 141: Business combinations. Norwalk, CT: Financial Accounting Standards Board.

FASB. 2001b. Statement of financial accounting standards (sfas) no. 142: Goodwill and other intangible assets. Norwalk, CT: Financial Accounting Standards Board.

Garten, J. E. 2001. Strengthening financial markets: Do investors have the information they need? Report of an SEC-Inspired Task Force (May).

Henning, S. L., and W. H. Shaw. 2003. Is the selection of the amortization period for goodwill a strategic choice? Review of Quantitative Finance \& Accounting 20 (4): 315.

Holthausen, R. W., and R. L. Watts. 2001. The relevance of the value-relevance literature for financial accounting standard setting. Journal of Accounting \& Economics 31 (1-3): 375.

Hopkins, P. E., R. W. Houston, and M. F. Peters. 2000. Purchase, pooling, and equity analysts' valuation judgments. Accounting Review 75 (3): 257.

IASB. 2004. International reporting financial standard (IFRS) no. 3: Business combinations. London: IASC Foundation Publications Department.

IASB. 2008. International reporting financial standard (IFRS) no. 3: Business combinations - revised. London: IASC Foundation Publications Department.

Jenkins, H. W. J. 1999. Business world: Mean old fasb: Forcing us to think. The Wall Street Journal 2nd June.

Jennings, R., J. Robinson, R. B. Thompson Ii, and L. Duvall. 1996. The relation between accounting goodwill numbers and equity values. Journal of Business Finance \& Accounting 23 (4): 513-533.

Kanodia, C., H. Sapra, and R. Venugopalan. 2004. Should intangibles be measured: What are the economic trade-offs? Journal of Accounting Research 42 (1): 89-120.

Lys, T., and L. Vincent. 1995. An analysis of value destruction in at\&t's acquisition of ncr. Journal of Financial Economics 39 (2/3): 353-378. 
Maines, L. A., E. Bartov, P. M. Fairfield, D. E. Hirst, T. A. Iannaconi, R. Mallett, C. M. Schrand, D. J. Skinner, and L. Vincent. 2003. Implications of accounting research for the fasb's initiatives on disclosure of information about intangible assets. Accounting Horizons 17 (2): 175-185.

McGoldrick, B. 1997. Goodwill games. Institutional Investor 31 (3): 145-149.

Ohlson, J. A. 1995. Earnings, book values, and dividends in equity valuation. Contemporary Accounting Research 11 (2): 661-687.

Ramanna, K. 2008. The implications of unverifiable fair-value accounting: Evidence from the political economy of goodwill accounting. Journal of Accounting and Economics 45: 253-281.

Ramanna, K., and R. L. Watts. 2009. Evidence from goodwill non-impairments on the effects of using unverifiable estimates in financial reporting. Working Papers -- Harvard Business School Division of Research: 1-41.

Shalev, R. 2009. The information content of business combination disclosure level. The Accounting Review 84 (1): 239-270.

Skinner, D. J. 2008. Accounting for intangibles - a critical review of policy recommendations. Accounting \& Business Research 38 (3): 191-204.

Subramanyam, K. R. 1996. The pricing of discretionary accruals. Journal of Accounting \& Economics 22 (1-3): 249-281.

Vincent, L. 1997. Equity valuation implications of purchase versus pooling accounting. Journal of Financial Statement Analysis 2 (4): 5.

Watts, R. L. 2003. Conservatism in accounting part i: Explanations and implications. Accounting Horizons 17 (3): 207-221.

Zhang, I., and Y. Zhang. 2007. Accounting discretion and purchase price allocation after acquisitions. Hong Kong University of Science and Technology. 
Table 1 - Descriptive Statistics of the Sample

Panel A $-1^{\text {st }}$ Step Variables

\begin{tabular}{lcccccc}
\hline & $\mathbf{N}$ & Mean & St-dev. & $\mathbf{1}^{\text {st }} \mathbf{Q}$ & Med & $\mathbf{3}^{\text {rd }} \mathbf{Q}$ \\
\hline Price & 265 & 3.173 & 2.819 & 1.429 & 2.235 & 3.540 \\
GW & 260 & 1.813 & 1.852 & 0.713 & 1.193 & 2.210 \\
\%GW & 276 & 0.572 & 0.284 & 0.422 & 0.589 & 0.734 \\
Materiality & 278 & 0.332 & 0.340 & 0.093 & 0.230 & 0.496 \\
Intan & 265 & 0.768 & 1.011 & 0.205 & 0.481 & 0.887 \\
Growth & 250 & 4.026 & 6.151 & 1.751 & 2.765 & 4.277 \\
Premium & 251 & 0.743 & 2.556 & 0.238 & 0.413 & 0.650 \\
Accruals & 272 & -0.003 & 0.094 & -0.033 & 0.006 & 0.041 \\
BIG4 & 279 & 0.950 & & & & \\
Health & 281 & 0.338 & & & & \\
Industry & 281 & 0.096 & & & & \\
HighTech & 281 & 0.505 & & & & \\
Nrj & 281 & 0.060 & & & & \\
\hline
\end{tabular}

Price is the purchase price scaled by the total assets of the target firm (from Thomson One Banker and Compustat). $G W$ is the amount of the purchase price allocated to goodwill scaled by the total assets of the target company (from acquirers' $10-\mathrm{Q} / \mathrm{K}$ and Compustat). $\% G W$ is the percentage of the purchase price allocated to goodwill (from acquirers' $10-\mathrm{Q} / \mathrm{K}$ A and Thomson One Banker). Materiality is the purchase price scaled by the total assets of the acquiring firm (from Thomson One Banker and Compustat). Intan is the amount of recognized intangible assets of the target firm scaled by the target firm total assets (from Compustat). Growth is the target company growth potential measured as the end of the year book-to-market ratio of the target (from Compustat annual and CRSP). Premium is excess purchase price over the market value of equity of the target company measured at the end of the month prior to the announcement expressed as a percentage of the market value of equity of the target company (from One Banker and CRSP monthly). Accruals is the acquiring firm total accruals measured as indicated in section 5.2. (from Compustat). BIG4 $=1$ if the auditor of the acquiring company belongs to one of the 4 largest external auditor (from firm $10-\mathrm{Q} / \mathrm{K}$ ). Health is a dummy variable equaling 1 if the acquiring firm macro industry is Healthcare (from Thomson One Banker). Industry is a dummy variable equaling 1 if the acquiring firm macro industry is Industrials (from Thomson One Banker). HighTech is a dummy variable equaling 1 if the acquiring firm macro industry is High Technology (from Thomson One Banker). $N r j$ is a dummy variable equaling 1 if the acquiring firm macro industry is Energy and Power (from Thomson One Banker). 
Panel B $-2^{\text {nd }}$ Step Variables (Forecasts' Revisions and Forecasts' Accuracy)

\begin{tabular}{lcccccc}
\hline & $\mathbf{N}$ & Mean & St-dev. & $\mathbf{1}^{\text {st }} \mathbf{Q}$ & Med & $\mathbf{3}^{\text {rd }} \mathbf{Q}$ \\
\hline Revision $_{E P S}$ & 241 & 0.117 & 0.256 & 0.003 & 0.031 & 0.098 \\
Revision $_{\text {EBIT }}$ & 191 & 0.259 & 0.716 & 0.002 & 0.036 & 0.192 \\
Revision $_{T P}$ & 238 & 0.118 & 0.251 & 0.008 & 0.032 & 0.076 \\
Revision $_{R E C O}$ & 245 & 0.043 & 0.063 & 0.000 & 0.018 & 0.057 \\
$\% T P($ mean) & 233 & 0.524 & & & & \\
$\% T P$ (median) & 231 & 0.519 & & & & \\
\hline
\end{tabular}

Revision $_{E P S}$ is the change in the consensus (mean) EPS following disclosure of the PPA (from $\mathrm{I} / \mathrm{B} / \mathrm{E} / \mathrm{S}$ ); Revision EBIT $_{\text {is }}$ the change in the consensus (mean) EBIT following disclosure of the PPA (from I/B/E/S); Revision ${ }_{T P}$ is the change in the consensus (mean) target price following disclosure of

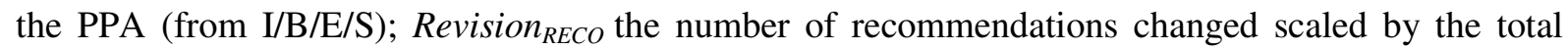
number of recommendations made by analysts following disclosure of the PPA (from I/B/E/S); \%TP (mean) is the percentage of the first mean consensus target price after disclosure of the PPA hit by actual security prices over the next 12 month (from I/B/E/S and CRSP); \%TP (median) is the percentage of the first median consensus target price after disclosure of the PPA hit by actual security prices over the next 12 month (from I/B/E/S and CRSP).

Panel C $-2^{\text {nd }}$ Step Variables (Dispersion and Forecasts' Errors)

\begin{tabular}{lcccccc}
\hline & $\mathbf{N}$ & Mean & St-dev. & $\mathbf{1}^{\text {st }} \mathbf{Q}$ & Med & $\mathbf{3}^{\text {rd }} \mathbf{Q}$ \\
\hline$\triangle$ Disp $_{E P S}$ & 241 & -0.012 & 0.588 & -0.040 & 0.000 & 0.019 \\
$\Delta$ Disp $_{E B I T}$ & 191 & -0.043 & 0.670 & 0.000 & 0.000 & 0.018 \\
Disp $_{T P}$ & 222 & 0.007 & 0.179 & -0.063 & 0.000 & 0.037 \\
Error $_{E P S}$ & 228 & -0.020 & 0.322 & -0.039 & 0.000 & 0.008 \\
Error $_{E B I T}$ & 162 & -0.123 & 1.008 & -0.053 & 0.000 & 0.013 \\
\hline
\end{tabular}

$\triangle$ Disp $_{E P S}$ is the change in EPS range after disclosure of the PPA (from $\mathrm{I} / \mathrm{B} / \mathrm{E} / \mathrm{S}$ ); $\triangle$ Disp $_{E B I T}$ is the change in EBIT range after disclosure of the PPA (from I/B/E/S); $\triangle D_{i s p} p_{T P}$ is the change in target price range after disclosure of the PPA (from $\mathrm{I} / \mathrm{B} / \mathrm{E} / \mathrm{S}$ ); ${ }_{E^{2}}$ rror $_{E P S}$ is the change after the disclosure of the PPA in the difference between EPS forecasts and actual EPS scaled by actual EPS (from I/B/E/S); $\triangle$ Error $_{E B I T}$ is the change after the disclosure of the PPA in the difference between EBIT forecasts and actual EBIT scaled by actual EBIT (from I/B/E/S).

Panel D - PPA and Subsequent Goodwill Impairments

\begin{tabular}{lcccccc}
\hline & $\mathbf{N}$ & Mean & St-dev. & $\mathbf{1}^{\text {st }} \mathbf{Q}$ & Med & $3^{\text {rd }} \mathbf{Q}$ \\
\hline Imp (\% EBITDA) & 175 & 0.400 & 1.337 & 0.000 & 0.000 & 0.097 \\
ImpTA (\% TA) & 175 & 0.072 & 0.160 & 0.000 & 0.000 & 0.039 \\
Perf & 175 & 0.116 & 0.060 & 0.083 & 0.116 & 0.156 \\
AbGW & 157 & 0.904 & 0.986 & 0.308 & 0.632 & 0.981 \\
\hline
\end{tabular}

$\operatorname{Imp}(\%$ EBITDA) is the cumulated goodwill impairment during the years following completion of the acquisition (with a maximum of three years after) as a percentage of three-year cumulated EBITDA. ImpTA (\% TA) is the cumulated goodwill impairment during years following completion of the acquisition (with a maximum of three years) as a percentage of acquirer's three-year mean total assets). Perf is the three-year mean performance of the acquirer measured as return on assets 
(EBITDA/Total Assets). $A b G W$ is the abnormal goodwill estimated from model (1) measuring the quality of PPAs. 
Panel E - Correlation Matrix between $1^{\text {st }}$ Stage Variables (P-Value are indicated in parenthesis)

\begin{tabular}{|c|c|c|c|c|c|c|c|c|c|c|c|c|c|}
\hline & Pricetat & GWtat & $G W p c$ & Materiality & Intant & Growth & Premium & Accruals & $B I G 4$ & Health & Industry & HighTech & $N r j$ \\
\hline Pricetat & 1.000 & & & & & & & & & & & & \\
\hline GWtat & $\begin{array}{l}0.835 \\
(0.000)\end{array}$ & 1.000 & & & & & & & & & & & \\
\hline$G W p c$ & $\begin{array}{l}-0.042 \\
(0.495)\end{array}$ & $\begin{array}{l}0.330 \\
(0.000)\end{array}$ & 1.000 & & & & & & & & & & \\
\hline Materiality & $\begin{array}{l}0.078 \\
(0.205)\end{array}$ & $\begin{array}{l}0.020 \\
(0.747)\end{array}$ & $\begin{array}{l}-0.152 \\
(0.011)\end{array}$ & 1.000 & & & & & & & & & \\
\hline Intant & $\begin{array}{l}0.699 \\
(0.000)\end{array}$ & $\begin{array}{l}0.581 \\
(0.000)\end{array}$ & $\begin{array}{l}-0.101 \\
(0.103)\end{array}$ & $\begin{array}{l}-0.098 \\
(0.110)\end{array}$ & 1.000 & & & & & & & & \\
\hline Growth & $\begin{array}{l}0.382 \\
(0.000)\end{array}$ & $\begin{array}{l}0.395 \\
(0.000)\end{array}$ & $\begin{array}{l}0.074 \\
(0.246)\end{array}$ & $\begin{array}{l}-0.066 \\
(0.295)\end{array}$ & $\begin{array}{l}0.229 \\
(0.000)\end{array}$ & 1.000 & & & & & & & \\
\hline Premium & $\begin{array}{l}0.113 \\
(0.073)\end{array}$ & $\begin{array}{l}0.118 \\
(0.064)\end{array}$ & $\begin{array}{l}-0.076 \\
(0.229)\end{array}$ & $\begin{array}{l}-0.022 \\
(0.724)\end{array}$ & $\begin{array}{l}0.162 \\
(0.010)\end{array}$ & $\begin{array}{l}-0.039 \\
(0.538)\end{array}$ & 1.000 & & & & & & \\
\hline Accruals & $\begin{array}{l}0.014 \\
(0.817)\end{array}$ & $\begin{array}{l}0.058 \\
(0.359)\end{array}$ & $\begin{array}{l}-0.001 \\
(0.985)\end{array}$ & $\begin{array}{l}0.120 \\
(0.046)\end{array}$ & $\begin{array}{l}0.022 \\
(0.726)\end{array}$ & $\begin{array}{l}0.041 \\
(0.525)\end{array}$ & $\begin{array}{l}0.011 \\
(0.861)\end{array}$ & 1.000 & & & & & \\
\hline BIG4 & $\begin{array}{l}-0.019 \\
(0.758)\end{array}$ & $\begin{array}{l}-0.065 \\
(0.293)\end{array}$ & $\begin{array}{l}-0.023 \\
(0.702)\end{array}$ & $\begin{array}{l}0.072 \\
(0.232)\end{array}$ & $\begin{array}{l}-0.051 \\
(0.410)\end{array}$ & $\begin{array}{l}0.007 \\
(0.910)\end{array}$ & $\begin{array}{l}0.012 \\
(0.849)\end{array}$ & $\begin{array}{l}-0.021 \\
(0.729)\end{array}$ & 1.000 & & & & \\
\hline Health & $\begin{array}{l}0.208 \\
(0.000)\end{array}$ & $\begin{array}{l}0.023 \\
(0.704)\end{array}$ & $\begin{array}{l}-0.215 \\
(0.000)\end{array}$ & $\begin{array}{l}0.138 \\
(0.021)\end{array}$ & $\begin{array}{l}0.250 \\
(0.000)\end{array}$ & $\begin{array}{l}0.054 \\
(0.387)\end{array}$ & $\begin{array}{l}0.020 \\
(0.745)\end{array}$ & $\begin{array}{l}0.054 \\
(0.367)\end{array}$ & $\begin{array}{l}-0.077 \\
(0.197)\end{array}$ & 1.000 & & & \\
\hline Industry & $\begin{array}{l}-0.126 \\
(0.040)\end{array}$ & $\begin{array}{l}-0.090 \\
(0.146)\end{array}$ & $\begin{array}{l}0.110 \\
(0.067)\end{array}$ & $\begin{array}{l}0.055 \\
(0.354)\end{array}$ & $\begin{array}{l}-0.094 \\
(0.125)\end{array}$ & $\begin{array}{l}0.058 \\
(0.356)\end{array}$ & $\begin{array}{l}-0.032 \\
(0.605)\end{array}$ & $\begin{array}{l}0.067 \\
(0.267)\end{array}$ & $\begin{array}{l}0.075 \\
(0.210)\end{array}$ & $\begin{array}{l}-0.233 \\
(0.000)\end{array}$ & 1.000 & & \\
\hline HighTech & $\begin{array}{l}-0.060 \\
(0.323)\end{array}$ & $\begin{array}{l}0.099 \\
(0.109)\end{array}$ & $\begin{array}{l}0.200 \\
(0.001)\end{array}$ & $\begin{array}{l}-0.191 \\
(0.001)\end{array}$ & $\begin{array}{l}-0.110 \\
(0.072)\end{array}$ & $\begin{array}{l}-0.053 \\
(0.402)\end{array}$ & $\begin{array}{l}0.023 \\
(0.713)\end{array}$ & $\begin{array}{l}-0.165 \\
(0.006)\end{array}$ & $\begin{array}{l}0.000 \\
(0.989)\end{array}$ & $\begin{array}{l}-0.722 \\
(0.000)\end{array}$ & $\begin{array}{l}-0.329 \\
(0.000)\end{array}$ & 1.000 & \\
\hline$N r j$ & $\begin{array}{l}-0.113 \\
(0.064)\end{array}$ & $\begin{array}{l}-0.137 \\
(0.026)\end{array}$ & $\begin{array}{l}-0.125 \\
(0.037)\end{array}$ & $\begin{array}{l}0.059 \\
(0.324) \\
\end{array}$ & $\begin{array}{l}-0.132 \\
(0.031)\end{array}$ & $\begin{array}{l}-0.065 \\
(0.302)\end{array}$ & $\begin{array}{l}-0.050 \\
(0.429)\end{array}$ & $\begin{array}{l}0.154 \\
(0.010)\end{array}$ & $\begin{array}{l}0.058 \\
(0.329)\end{array}$ & $\begin{array}{l}-0.181 \\
(0.002)\end{array}$ & $\begin{array}{l}-0.082 \\
(0.166)\end{array}$ & $\begin{array}{l}-0.256 \\
(0.000)\end{array}$ & 1.000 \\
\hline
\end{tabular}


Table 2 - Explanation of Normal Goodwill

\begin{tabular}{|c|c|c|c|c|}
\hline \multirow[t]{2}{*}{ Dep Var: } & \multicolumn{4}{|c|}{$G W / T A$} \\
\hline & Exp. Sign & Coeff. & t-stat & P.Value \\
\hline Materiality & $(+/-)$ & $0.793^{* *}$ & 2.182 & 0.030 \\
\hline Growth & $(+)$ & $0.089 * *$ & 2.607 & 0.010 \\
\hline Premium & $(+)$ & 0.035 & 1.044 & 0.297 \\
\hline Intan & $(+)$ & $0.957 * * *$ & 5.657 & 0.000 \\
\hline BIG4 & $(-)$ & -0.135 & -0.277 & 0.782 \\
\hline Industry & $(+/-)$ & -0.010 & -0.036 & 0.971 \\
\hline$N r j$ & $(+/-)$ & -0.015 & -0.047 & 0.963 \\
\hline HighTech & $(+/-)$ & $0.759 * * *$ & 3.476 & 0.001 \\
\hline Two & $(+/-)$ & 0.484 & 0.829 & 0.408 \\
\hline Three & $(+/-)$ & 0.024 & 0.078 & 0.938 \\
\hline Four & $(+/-)$ & 0.358 & 1.019 & 0.309 \\
\hline Five & $(+/-)$ & $0.542 *$ & 1.774 & 0.077 \\
\hline Six & $(+/-)$ & 0.225 & 0.783 & 0.434 \\
\hline Seven & $(+/-)$ & 0.299 & 1.064 & 0.288 \\
\hline Eight & $(+/-)$ & $0.689 * *$ & 2.166 & 0.031 \\
\hline _cons & $(+/-)$ & -0.1646 & -0.2617 & 0.794 \\
\hline $\mathbf{R}^{2}$ & & 0.471 & & \\
\hline Adj. $R^{2}$ & & 0.436 & & \\
\hline $\mathbf{F}$ & & $8.163 * * *$ & & \\
\hline $\mathbf{p}(\mathbf{F})$ & & 0.000 & & \\
\hline $\mathbf{N}$ & & 241 & & \\
\hline
\end{tabular}

$* \mathrm{p}<.1$ (two-sided tests); $* * \mathrm{p}<.05$ (two-sided tests); $* * * \mathrm{p}<.01$ (two-sided tests) 
Table 3 - Association between PPAs' Quality and Analysts' Expectations

Panel A - Association with Analysts' Revisions

\begin{tabular}{|c|c|c|c|c|c|c|c|c|c|c|c|c|}
\hline \multirow[t]{2}{*}{ Dep Var: } & \multicolumn{3}{|c|}{ Revision $_{E P S}$} & \multicolumn{3}{|c|}{ Revision $_{\text {EBIT }}$} & \multicolumn{3}{|c|}{ Revision $_{T P}$} & \multicolumn{3}{|c|}{ Revision $_{R E C O}$} \\
\hline & Coeff. & t-stat & P.Value & Coeff. & t-stat & P.Value & Coeff. & t-stat & P.Value & Coeff. & t-stat & P.Value \\
\hline$a b G W 1$ & $-0.019 *$ & -1.932 & 0.055 & $-0.066^{*}$ & -1.784 & 0.076 & -0.001 & -0.096 & 0.923 & -0.001 & -0.251 & 0.801 \\
\hline _cons & 0.134 & 5.614 & 0.000 & 0.376 & 4.047 & 0.000 & 0.11 & 4.655 & 0.000 & 0.042 & 6.929 & 0.000 \\
\hline $\mathbf{R}^{2}$ & & 0.007 & & & 0.006 & & & 0.000 & & & 0.000 & \\
\hline Adj. $\mathbf{R}^{2}$ & & 0.002 & & & 0.000 & & & -0.005 & & & -0.005 & \\
\hline $\mathbf{F}$ & & $3.733^{*}$ & & & $3.183^{*}$ & & & 0.009 & & & 0.063 & \\
\hline $\mathbf{p}(\mathbf{F})$ & & 0.055 & & & 0.076 & & & 0.923 & & & 0.801 & \\
\hline $\mathbf{N}$ & & 207 & & & 166 & & & 206 & & & 211 & \\
\hline
\end{tabular}

${ }^{*} \mathrm{p}<.1$ (two-sided tests); ${ }^{*} \mathrm{p}<.05$ (two-sided tests); $* * * \mathrm{p}<.01$ (two-sided tests) 
Panel B - Association of PPA's Quality with Change of Forecasts' Dispersion

\begin{tabular}{|c|c|c|c|c|c|c|c|c|c|}
\hline \multirow[t]{2}{*}{ Dep Var } & \multicolumn{3}{|c|}{$\Delta D i s p_{E P S}$} & \multicolumn{3}{|c|}{$\Delta D i s p_{E B I T}$} & \multicolumn{3}{|c|}{$\Delta D i s p_{T P}$} \\
\hline & Coeff. & t-stat & P.Value & Coeff. & t-stat & P.Value & Coeff. & t-stat & P.Value \\
\hline$a b G W 1$ & -0.002 & -0.183 & 0.854 & -0.016 & -1.294 & 0.197 & 0.013 & 0.843 & 0.400 \\
\hline _cons & -0.028 & -0.769 & 0.443 & 0.005 & 0.399 & 0.690 & -0.006 & -0.332 & 0.740 \\
\hline$\overline{\mathbf{R}^{2}}$ & & 0.000 & & & 0.012 & & & 0.008 & \\
\hline Adj. $R^{2}$ & & -0.005 & & & 0.006 & & & 0.003 & \\
\hline $\mathbf{p}(\mathbf{F})$ & & 0.854 & & & 0.197 & & & 0.400 & \\
\hline $\mathbf{N}$ & & 207 & & & 166 & & & 193 & \\
\hline
\end{tabular}

Panel C - Association with Change in Forecasts' Accuracy

\begin{tabular}{|c|c|c|c|c|c|c|}
\hline \multirow[t]{2}{*}{ Dep Var: } & \multicolumn{3}{|c|}{$\Delta$ Error $_{E P S}$} & \multicolumn{3}{|c|}{$\Delta$ Error $_{E B I T}$} \\
\hline & Coeff. & t-stat & P.Value & Coeff. & t-stat & P.Value \\
\hline$a b G W 1$ & -0.002 & -0.184 & 0.854 & 0.055 & 0.843 & 0.401 \\
\hline _cons & -0.007 & -0.367 & 0.714 & -0.193 & -1.343 & 0.181 \\
\hline $\mathbf{R}^{2}$ & & 0.000 & & & 0.005 & \\
\hline Adj. $R^{2}$ & & -0.005 & & & -0.002 & \\
\hline $\mathbf{F}$ & & 0.009 & & & 0.996 & \\
\hline $\mathbf{p}(\mathbf{F})$ & & 0.926 & & & 0.320 & \\
\hline $\mathbf{N}$ & & 189 & & & 136 & \\
\hline
\end{tabular}


Panel D - Association with Target Prices’ Accuracy after Disclosure

\begin{tabular}{|c|c|c|c|c|c|c|}
\hline \multirow[t]{2}{*}{ Dep Var } & \multicolumn{3}{|c|}{$\% T P($ mean $)$} & \multicolumn{3}{|c|}{$\% T P($ median $)$} \\
\hline & Coeff. & t-stat & P.Value & Coeff. & t-stat & P.Value \\
\hline$a b G W 1$ & $-0.198 * *$ & -2.087 & 0.037 & $-0.185^{*}$ & -1.941 & 0.052 \\
\hline _cons & 0.245 & 1.943 & 0.052 & 0.219 & 1.738 & 0.082 \\
\hline Pseudo $\mathbf{R}^{2}$ & & 0.016 & & & 0.014 & \\
\hline chi2 & & $4.511 * *$ & & & $3.889^{* *}$ & \\
\hline p(chi2) & & 0.034 & & & 0.049 & \\
\hline $\mathbf{N}$ & & 203 & & & 201 & \\
\hline
\end{tabular}


Table 4 - Proxy for PPAs Quality: Robustness' Checks

Panel A - Association between PPAs'Quality and Subsequent Goodwill Impairments

\begin{tabular}{|c|c|c|c|c|c|c|c|}
\hline \multirow[t]{2}{*}{ Dep Var } & \multirow[b]{2}{*}{ Exp. Sign } & \multicolumn{3}{|c|}{$\operatorname{Imp}(\%$ EBITDA) } & \multicolumn{3}{|c|}{$\operatorname{ImpTA}(\%$ TA) } \\
\hline & & Coeff. & t-stat & P.Value & Coeff. & t-stat & P.Value \\
\hline AvPerf & $(-)$ & $-9.216 * *$ & -2.539 & 0.012 & $-0.718 * * *$ & -3.020 & 0.003 \\
\hline LowPerf $* A b G W$ & $(-)$ & $-0.288 *$ & -1.899 & 0.059 & $-0.033 * *$ & -2.385 & 0.018 \\
\hline _cons & $(+/-)$ & 1.566 & 2.901 & 0.004 & 0.163 & 4.356 & 0.000 \\
\hline $\mathbf{R}^{2}$ & & & 0.122 & & & 0.056 & \\
\hline Adj. $R^{2}$ & & & 0.111 & & & 0.043 & \\
\hline $\mathbf{F}$ & & & $3.241 * *$ & & & $4.748 * *$ & \\
\hline $\mathbf{p}(\mathbf{F})$ & & & 0.042 & & & 0.01 & \\
\hline $\mathbf{N}$ & & & 157 & & & 157 & \\
\hline
\end{tabular}

Panel B - Association between PPAs Quality and Total Accruals

\begin{tabular}{|c|c|c|c|}
\hline \multirow[t]{2}{*}{ Dep. Var: } & \multicolumn{3}{|c|}{$A b G W$} \\
\hline & Coeff. & t-stat & P.Value \\
\hline Accruals** & 1.518 & 2.469 & 0.014 \\
\hline _cons & 0.965 & 15.11 & 0.000 \\
\hline $\mathbf{R}^{2}$ & 0.019 & & \\
\hline Adj. $R^{2}$ & 0.015 & & \\
\hline $\mathbf{F}$ & $6.10^{* *}$ & & \\
\hline $\mathbf{p}(\mathbf{F})$ & 0.014 & & \\
\hline $\mathbf{N}$ & 236 & & \\
\hline
\end{tabular}


Table 5 - Returns Following Disclosure based on Ranking of PPAs' Quality

Panel A - Cumulated Abnormal Returns (CAR) based on Quintile of PPA's Quality (days +2 to +50 after Disclosure)

\begin{tabular}{lcccc}
\hline Portfolio & $\mathrm{N}$ & $\begin{array}{c}\text { Mean CAR } \\
(+2,+50)\end{array}$ & $\begin{array}{c}\text { Portfolio Time- } \\
\text { Series (CDA) t }\end{array}$ & p-Value \\
\hline Top 20\% of PPAs Quality & 46 & $2.12 \% * *$ & 0.869 & 0.1942 \\
Top 20\% to 40\% of PPAs Quality & 50 & $0.38 \%$ & 0.151 & 0.4401 \\
Top 40\% to 60\% of PPAs Quality & 43 & $-0.41 \%$ & -0.156 & 0.4379 \\
Top 60\% to 80\% of PPAs Quality & 42 & $-2.83 \%$ & -1.148 & 0.1255 \\
Bottom 20\% of PPAs Quality & 47 & $-4.36 \% * *$ & -1.875 & 0.0304 \\
\hline \multicolumn{2}{c}{$*$ p $<.1$ (two-sided tests); **p<.05(two-sided tests); ***p<.01 (two-sided tests) }
\end{tabular}

Panel B - Buy and Hold Returns based on Quintile of PPA's Quality (days +2 to +50 after Disclosure)

\begin{tabular}{lccc}
\hline Portfolio & N & $\begin{array}{c}\text { Mean Buy and Hold } \\
\text { return }\end{array}$ & $\begin{array}{c}\text { Median Buy and } \\
\text { Hold return }\end{array}$ \\
\hline Top 20\% of PPAs Quality & 46 & $3.10 \%$ & $5.94 \%$ \\
Top 20\% to 40\% of PPAs Quality & 50 & $6.32 \%$ & $3.42 \%$ \\
Top 40\% to 60\% of PPAs Quality & 43 & $3.63 \%$ & $2.80 \%$ \\
Top 60\% to 80\% of PPAs Quality & 42 & $-0.02 \%$ & $0.26 \%$ \\
Bottom 20\% of PPAs Quality & 47 & $-1.08 \%$ & $0.62 \%$ \\
\hline
\end{tabular}


Figure 1 - Time Series of CARs for the 5 Portfolios after PPAs Disclosure (+2, +50 days)

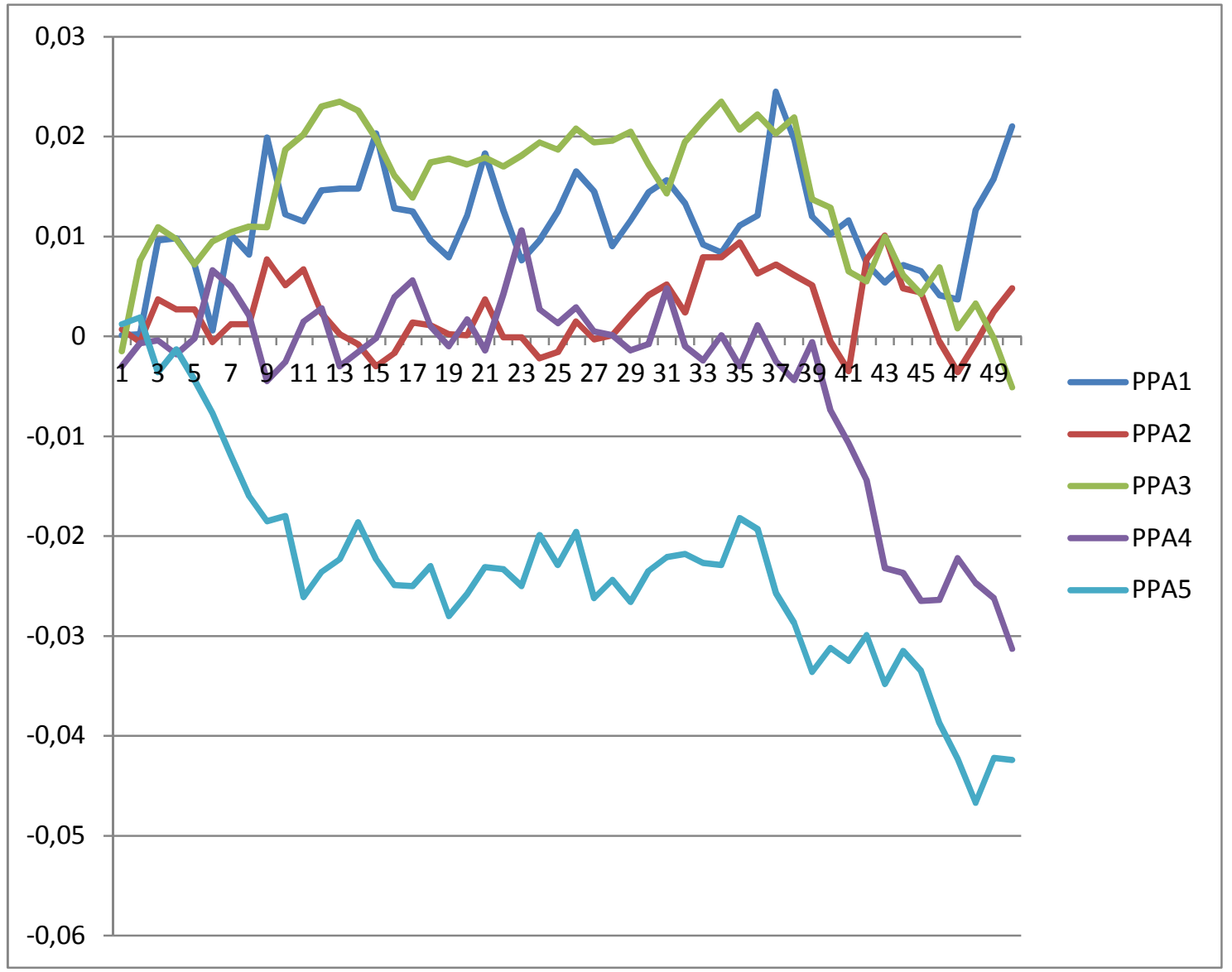

